\title{
Meningkatkan Efektivitas Belajar Lempar Cakram dengan Menggunakan Media Modifikasi Piring Plastik pada Siswa Kelas VI SDN 1 Darmaji Tahun Pelajaran 2016/2017
}

\author{
TERANG \\ Guru PJOK SDN 1 Darmaji \\ Kecamatan Kopang Kab Lombok Tengah
}

\begin{abstract}
Abstrak; Penelitian Tindakan Kelas dengan judul "Meningkatkan Efektivitas Belajar PJOK Materi Lempar Cakram dengan Menggunakan Media Modifikasi Piring Plastik pada Siswa Kelas VI SDN 1 Darmaji Tahun Pelajaran 2016/2017, jumlah sampel dalam penelitian ini sebanyak 28 Siswa yang terdiri dari 12 putra dan 16 putri perempuan. Dengan hasil penelitian sebagai berikut; Pertama, aktivitas siswa selama mengikuti proses pembelajaran lempar cakram dengan menggunakan media modifikasi piring plastik di kategorikan aktif. Dan setelah dilakukan siklus kedua, aktivitas siswa mengalami peningkatan keaktifan rata-rata sebesar $75 \%$. Kalau mengacu pada indikator keaktifan siswa maka besaran keaktifan sebesar $75 \%$ termasuk kriteria aktif. Kedua, bahwa aktivitas mengajar guru pada siklus pertama mencapai tingkat pencapaian $95 \%$, sedangkan pada siklus kedua setelah melakukan treatment pada proses pembelajaran, aktivitas guru mencapai $100 \%$. Ini berarti ada kenaikan aktivitas guru sebesar 5\%, sehingga rata-rata aktivitas guru pada dua siklus mencapai 97,5\%. Mengacu pada indikator aktivitas guru , besaran angka 97,5\% termasuk kriteria sangat aktif. Ketiga rata-rata ketuntasan belajar untuk aspek awalan mencapai 97,5\% putra dan putri mencapai 75\%. mengacu pada indikator hasil belajar siswa pada tabel 1, persentase tersebut menunjukan bahwa pembelajaran awalan pada lempar cakram dengan menggunakan media modifikasi piring plastik, berkategori sangat efektif untuk putra dan efektif untuk putri. Rata-rata ketuntasan belajar untuk aspek cara melempar mencapai $85 \%$ putra dan putri mencapai $70 \%$. Mengacu pada Indikator hasil belajar siswa pada Tabel 1, persentase tersebut menunjukan bahwa pembelajaran cara melempar pada lempar cakram dengan menggunakan media modifikasi piring plastik, berkategori sangat efektif untuk putra dan efektif untuk putri. Rata-rata Ketuntasan Belajar untuk aspek sikap akhir mencapai $85 \%$ putra dan putri mencapai 72,5\%. Mengacu pada indikator hasil belajar siswa pada tabel 1, persentase tersebut menunjukan bahwa pembelajaran sikap akhir pada lempar cakram dengan menggunakan media modifikasi piring plastik, berkategori sangat efektif untuk putra dan efektif untuk putri. Berdasarkan hasil penelitian tersebut maka penggunaan media modifikasi piring plastik dapat dijadikan sebagai salah satu refrensi dalam pemebelajaran PJOK.
\end{abstract}

Kata kunci: Media modifikasi, piring plastik, efektivitas pembelajaran

\section{PENDAHULUAN}

Sarana prasarana merupakan salah satu bagian yang strategis dalam pencapaian tujuan pembelajaran. Dengan kata lain, lengkap dan tidak lengkapnya sarana prasarana pembelajaran turut mempengaruhi maksimal dan tidak maksimalnya ketercapaian tujuan pembelajaran. Sarana yang lengkap bisa memudahkan guru untuk mengejar target-target tertentu yang menjadi tujuan pembelajaranya. Begitu sebaliknya, sarana yang tidak lengkap akan menyulitkan bagi guru dalam mencapai target-target tujuan pembelajaranya.
Ini pula yang terjadi pada pembelajaran Lempar Cakram di SD Negeri I, Kondisi nyata di sekolah, media Cakram hanya tersedia 2 buah, 1 untuk putri dan 1 untuk putra. Sementara jumlah siswa kelas VI SD Negeri I Darmaji berjumlah 28 siswa jadi komparasi antara jumlah Cakram dan jumlah siswa adalah 1 : 14 putra/putri. Jelas dari gambaran tersebut bahwa proses pembelajaran Lempar Cakram menjadi tidak efektif, dan akibatnya bahwa target kurikulum menjadi sangat rendah.

Situasi dan kondisi ini sudah berjalan cukup lama dan sekolah sampai detik ini belum bisa memenuhi sarana Cakram tersebut 
sampai batas yang cukup memadai atau kondisi ideal, misalnya dengan perbandingan $1: 2$ ( 1 cakram untuk 2 orang ). Hal ini bisa dimengerti, karena sekolah mempunyai kebutuhan yang sangat banyak dan hampir semuanya mempunyai tingkat urgensitas yang tinggi untuk di penuhi oleh sekolah. Sehingga menuntut sekolah untuk menyediakan Cakram sesuai dengan kondisi ideal, merupakan suatu yang tidak realistis dan lebih jauhnya bisa menimbulkan gejolak dan iklim yang tidak kondusif di sekolah.

Oleh karena itu perlu sebuah pemecahan masalah yang sederhana dan bisa dilakukan oleh guru. Melihat permasalahan di atas, maka satu pemikiran yang muncul adalah bahwa perlu adanya sebuah media alternatif modifikatif untuk mengganti cakram yang memang cukup mahal. Media alternatif modifikatif tersebut harus bersifat bisa mewakili karakteristik cakram, murah, banyak tersedia atau mudah di dapat.

Dari beberapa kriteria media alternatif modifikatif untuk mengganti cakram tersebut nampaknya piring plastik bisa dijadikan media alternatif modifikatif untuk mengganti cakram. Dari segi bentuk, jelas ada kemiripan dengan bentuk cakram, dari segi ketersediaan dan harga, maka piring plastik sangat mudah sekali di dapat di pasar-pasar tradisional dengan harga sangat murah.

Dari permasalahan tersebut di atas maka penulis menentukan judul Penelitian Tindakan Kelas ini "Meningkatkan Efektivitas Belajar PJOK Materi Lempar Cakram dengan Media Modifikasi Piring Plastik, pada Siswa Kelas VI SD Negeri 1 Darmaji Tahun pelajaran 2016/2017"

\section{Rumusan Masalah}

Dari latar belakang tersebut di atas, maka Rumusan Penelitian ini adalah bagaimanakah Meningkatkan Efektivitas Belajar PJOK Materi Lempar Cakram dengan Media Modifikasi Piring Plastik, pada Siswa Kelas VI SD Negeri 1 Darmaji Tahun pelajaran 2016/2017?"

\section{Tujuan Penelitian}

Tujuan umum dari Penelitian Tindakan Kelas ini adalah untuk Meningkatkan Efektivitas Belajar PJOK Materi Lempar Cakram dengan Media Modifikasi Piring
Plastik, pada Siswa Kelas VI SD Negeri 1 Darmaji Tahun pelajaran 2016/2017"

\section{Manfaat}

Manfaat dari penelitian ni adalah dengan media modifikasi siswa lebih partisipatif dalam proses pembelajaran Lempar Cakram , membuat pengajaran Lempar Cakram menjadi lebih efektif dan dapat dijadikan sebagai salah satu alternatif untuk memenuhi kekurangan media pembelajaran.

\section{KAJIAN PUSTAKA Belajar}

Dalam keseluruhan proses pendidikan di sekolah, pembelajaran merupakan aktivitas yang paling utama. Ini berarti bahwa keberhasilan pencapaian tujuan pendidikan banyak tergantung pada proses pembelajaran. Apakah pembelajaran itu?

Untuk menjawab pertanyaan tersebut, ada baiknya di kemukakan sebuah definisi dari pembelajaran " Pembelajaran ialah suatu proses yang dilakukan oleh individu untuk memperoleh suatu perubahan perilaku yang baru secara keseluruhan, sebagai hasil dari pengalaman individu itu sendiri dalam interaksi dengan lingkungannya " (Surya:2014). Menurut Surya (2014) lebih lanjut bahwa ada beberapa prinsip yang menjadi landasan pengertian tersebut di atas ialah :

Pertama, pembelajaran sebagai usaha memperoleh perubahan perilaku. Prinsip ini mengandung makna bahwa ciri utama proses pembelajaran itu adalah adanya perubahan perilaku dalam diri individu. Artinya seseorang telah mengalami pembelajaran akan berubah perilakunya. Tetapi tidak semua perubahan perilaku sebagai hasil pembelajaran. Perubahan perilaku sebagai hasil pembelajaran mempunyai cirri-ciri sebagai berikut : (a) perubahan yang disadari, artinya individu yang melakukan proses pembelajaran menyadari bahwa pengetahuan, keterampilan, dan ia lebih yakin terhadap dirinya. (b). Perubahan bersifat kontinyu (berkesinambungan) Artinya suatu perubahan yang terjadi, meyebebkan terjadinya perubahan perilaku yang lain. (c). Perubahan bersifat fungsional, artinya perubahan yang telah diperoleh sebagai hasil pembelajaran memberikan manfaat bagi individu yang 
bersangkutan. (d) perubahan bersifat positif, artinyaterjadi adanya pertambahan perubahan dalam diri individu (e) Perubahan yang bersifat aktif, artinya perubahan itu terjadi dengan sednirinya, akan tetapi memlalui aktivitas individu. (f). Perubahan yang bersifat permanent (menentap) , artinya perubahan yang terjadi sebagai hasil pembelajaran akan berada secara kekal dalam diri individu, setidak-tidaknya untuk masa tetentu. (g). Perubahan yang bertujuan dan terarah, artinya perubahan itu terjadi karena ada sesuatu yang akan yang akan dicapai.

Kedua, Hasil pembelajaran ditandai dengan perubahan perilaku secara keseluruhan. Prinsip ini mengandung makna bahwa perubahan perilkau sebagai hasil pembelajaran adalah meliputi aspek kognitif, afektif dan psikomotor.

Ketiga, pembelajaran merupakan suatu proses. Prinsip ketiga ini mengandung makna bahwa pembelajaran itu merupakan suatu aktivitas yang berkesinambungan.

Keempat, proses pembelajaran terjadi karena adanya sesuatu yang mendorong dan ada sesuatu tujuan yang akandi capai. Peinsip ini mengandung makna bahwa aktivitas pembelajaran itu terjadi karena adanya kebutuhan yang harus dipuaskan, dan adanya tujuan yang ingin dicapai. Kelima, pembelajaran merupakan bentuk pengalaman. Pengalaman pada dasarnya adalah kehidupan melalui situasi yang nyata dengan tujuan tertentu.

\section{Efektivitas Belajar}

Efektivitas merupakan aspek penting dalam berbagai bentuk kegiatan, karena efektivitas merupakan cerminan dari tingkat keberhasilan dalam mencapai tujuan atau sasaran yang ingin dicapai. Rivai dengan mengutip Exzioni (1964) menuliskan bahwa efektivitas adalah sebagai tingkat keberhasilan dalam mencapai tujuan dan sasarannya.

Efektivitas tidak hanya dapat dilihat dari sisi produktivitas, akan tetapi dapat pula dilihat dari sisi persepsi atau sikap orangnya. Disamping itu, efektivitas juga dapat dilihat dari bagaimana tingkat kepuasaan yang dicapai oleh orang (Robbins, 1977 dikutip oleh Rivai). Masih dari Rivai dengan mengutip Prokovenko (1987) dan Miskel
(1992) dengan demikian efektivitas merupakan suatu konsep yang sangat penting kerena mampu memberikan gambaran mengenai keberhasilan seseorang dalam mencapai sasaran atau suatu tingkatan terhadap mana tujuan-tujuan dicapai atau tingkat pencapaian tujuan.

Dan dalam kaitannya dengan efektivitas belajar Rivai ( ), mengatakan bahwa efektivitas belajar adalah tingkat pencapaian tujuan pelatihan. Pencapain tujuan tersebut berupa peningkatan pengetahuan dan keterampilan serta pengembangan sikap melalui proses pembelajaran.

Menurut Rivai aspek-aspek yang meliputi efektivitas belajar adalah: (1) Peningkatan pengetahuan, (2) Peningkatan keterampilan, (3) Perubahan sikap, (4) Prilaku, (5) Kemampuan adaptasi, (6) Peningkatan integrasi, (7) Peningkatan partisipasi, (8) Peningkatan interaksi cultural

\section{Media Belajar}

Media berasal dari bahasa Latin merupakan bentuk jamak dari medium yang secara harfiah berarti, perantara atau pengantar, yaitu perantara atau pengantar sumber pesan dengan penerima pesan. Beberapa ahli yang dikutip Sudrajat memberikan definisi tentang media pembelajaran diantaranya, schram (2007) mengemukakan bahwa media pembelajaran adalah teknologi pembawa pesan yang dapat dimanfaatkan untuk keperluan pembelajaran.

Sementara, Briggs (2007) berpendapat bahwa media pembelajaran adalah sarana fisik untuk menyampaikan isi/ materi pembelajaran seperti : buku, film, video dan sebagainya. Sedangkan National Education Association (1969) mengungkapkan bahwa media pembelajaran adalah sarana komunikasi dalam bentuk cetak maupun pandang-dengar, termasuk teknologi perangkat keras.

Dari ketiga pendapat di atas dapat disimpulkan bahwa media pembelajaran adalah segala sesuatu yang dapat menyalurka pesan, dapat merangsang pikiran, perasaan, dam kemauan peserta didik sehingga dapat mendorong terciptanya proses belajar pada diri peserta didik. Dalam kaitanya dengan efektivitas belajar Brown (1973) yang juga 
dikutip Sudrajat mengengkapkan bahwa media pembelajaran yang digunakan dalam kegiatan pembelajaran dapat mempengaruhi tehadap efektivitas pembelajaran.

Lebih lanjut Sudrajat (2007) menuliskan tentang beberapa fungsi media diantaranya : (1). Media pembelajaran dapat melampaui batasan ruang kelas. Banyak hal yang tidak mungkin dialami secara langsung di dalam kelas oleh peserta didik tentang suatu objek, disebabkan : (a). objek terlalu besar; (b). objek terlalu kecil; (c). objek yang bergerak terlalu lambat; (d). objek yang bergerak terlalu cepat; (e). objek yang terlalu komplek; (f). objek yang bunyinya terlalu halus; (g). objek mangandung bajaya dan resiko tinggi. Melalui penggunaan nedia yang tepat, maka semua objek dapat disajikan kepada peserta didik. (2). Media pembelajaran memungkinkan adanya interaksi langsung antara peserta didik dengan lingkungannya; (3). Media membangkitkan motivasi dan merangsang anak untuk belajar; (4). Media memberikan pengalaman yang integral/menyeluruh dari yang konkrit sampai dengan yang bastrak.

\section{METODE PENELITIAN}

\section{Tempat, Waktu dan Subyek Penelitian}

Penelitian Tindakan Kelas dengan judul "Meningkatkan Efektivitas Belajar PJOK Materi Lempar Cakram dengan Media Modifikasi Piring Plastik pada Siswa Kelas V SDN 1 darmaji Tahun pelajaran 2016/2017““ ini dilaksanakan di kelas VI SD Negeri 1 Darmaji, J1. Kabupaten Praya - Kopang, kilometer 8 dari kota kecamatan.

Penelitian ini dilaksanakan dari tanggal 11 Januari s.d 30 Maret 2017 dengan subjek penelitian adalah siswa kelas VI SD Negeri 1 Darmaji dengan jumlah siswa putri 16 orang dan putra 12 orang, jadi jumlah total 28 orang siswa.

\section{Indikator Efektivitas Belajar}

Penelitian Tindakan Kelas ini adalah untuk mengukur sejauh mana efektivitas belajar Lempar Cakram dengan menggunakan media modifikasi piring plastik, indikator dari efektivitas belajar adalah meningkatnya hasil belajar siswa (Rivai: ), dengan kata lain bahwa untuk melihat efektif tidaknya sebuah proses pembelajaran bisa dilihat dari pencapaian hasil pembelajarannya. Berikut ini Tabel 1 Indikator Hasil Belajar Siswa.

\begin{tabular}{|c|l|c|l|}
\multicolumn{5}{|c|}{ Tabel 4indikator Respon (Tingkat Kepuasan Belajar) Siswa } \\
\hline \multirow{2}{*}{ No } & \multicolumn{1}{|c|}{ Aspek } & $\begin{array}{c}\text { Tingkat Kepuasaan } \\
\text { Belajar Siswa }\end{array}$ & \multicolumn{1}{|c|}{ Kriteria } \\
\hline 1 & Respon siswa & $80-100 \%$ & Sangat Pulas \\
& terhadap proses & $60-79 \%$ & Puas \\
& Belajar Lempar & $40-59 \%$ & Cukup Puas \\
& Cakram & $20-39 \%$ & Kurang Puas \\
& & $0-19 \%$ & Tidak Pulas \\
\hline
\end{tabular}

\begin{tabular}{|c|l|c|l|}
\hline \multicolumn{4}{|c|}{ Tabel 1Indikator Hasil Belajar Siswa } \\
\hline \multirow{2}{*}{ No } & \multicolumn{1}{|c|}{ Aspek } & Ketuntasan & \multicolumn{1}{|c|}{ Kriteria } \\
\hline 1 & Awalan & $80-100 \%$ & Sangat Efektif \\
& & $60-79 \%$ & Efektif \\
& & $40-59 \%$ & Cukup efektif \\
& & $20-39 \%$ & Kurang efektif \\
& & $0-19 \%$ & Tidak efektif \\
\hline 2 & Cara Melempar & $80-100 \%$ & Sangat Efektif \\
& & $60-79 \%$ & Efektif \\
& & $40-59 \%$ & Cukup efektif \\
& & $20-39 \%$ & Kurang efektif \\
& & $0-19 \%$ & Tidak efektif \\
\hline 3 & Sikap Akhir & $80-100 \%$ & Sangat Efektif \\
& & $60-79 \%$ & Efektif \\
& & $40-59 \%$ & Cukup efektif \\
& & $20-39 \%$ & Kurang efektif \\
& & $0-19 \%$ & Tidak efektif \\
\hline
\end{tabular}

Tabel2

Intikator Keakififan Siswra

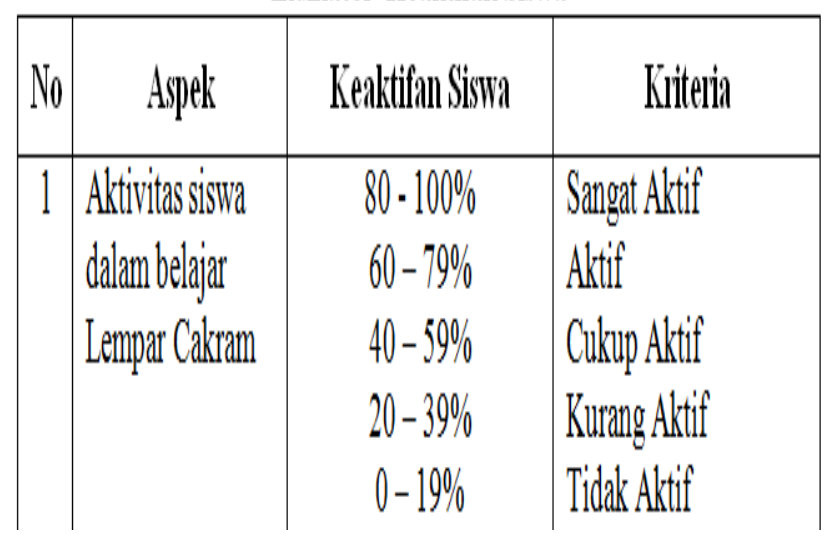




\section{Gambaran Umum Penelitian}

Rancangan penelitian ini adalah Penelitian Tindakan Kelas. Prosedur atau langkah-langkah yang akan dilakukan dalam penelitian ini dilaksanakan dalam kegiatan yang berbentuk siklus penelitian. Setiap siklus penelitian terdiri dari empat kegiatan pokok yaitu, perencanaan, tindakan pelaksanaan, observasi, dan refleksi

\section{Teknik Pengumpulan Data}

Untuk mengumpulkan data penelitian, dilakukan dengan cara menentukan sumber data terlebih dahulu, kemudian jenis data, teknik pengumpulan data, dan instrumen yang digunakan. Teknik pengumpulan data secara lengkap dapat dilihat pada Tabel 5 di bawah ini :

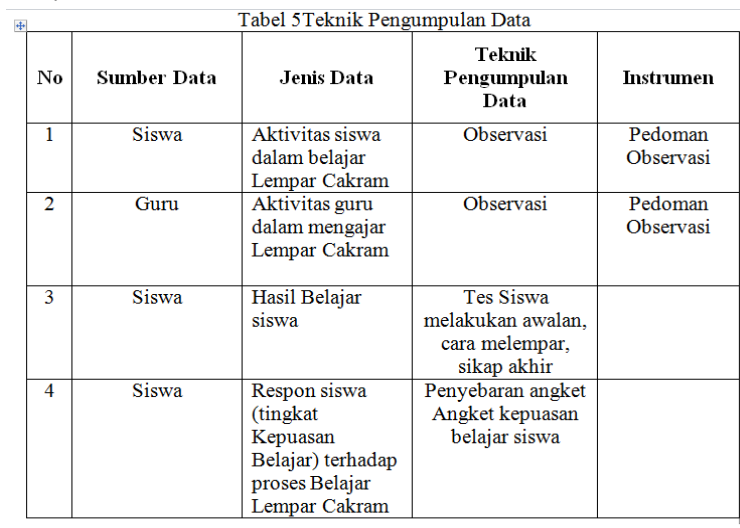

\section{Rencana Penelitian}

Rencana yang disusun untuk penelitian ini , diawali dengan kegiatan studi awal, refleksi awal, pelaksanaan siklus penelitian, dan penarikan kesimpulan.

\section{HASIL PENELITIAN}

Berdasarkan hasil 2 siklus penelitian, peneliti bersama rekan guru yang bertindak sebagai kolaborator yang melakukan pengamatan, melakukan diskusi dan refleksi, maka di dapat hasil seperti terlihat pada Tabel.

\begin{tabular}{|c|c|c|c|}
\hline No & Aspek Penelitian & $\begin{array}{c}\text { Siklus } \\
\text { Penelitian }\end{array}$ & Tindakan \\
\hline 1 & $\begin{array}{l}\text { Aktivitas siswa dalam } \\
\text { belajar Lempar Cakram }\end{array}$ & $70 \%$ & $\begin{array}{l}\text { Perlu ditingkatkan dengan } \\
\text { berbagai formasi dan } \\
\text { permainan }\end{array}$ \\
\hline 2 & $\begin{array}{l}\text { Aktivitas guru dalam } \\
\text { mengajar Lempar Cakram }\end{array}$ & $95 \%$ & $\begin{array}{l}\text { Perlu ditingkatkan dengan } \\
\text { melihat kembali RPP }\end{array}$ \\
\hline 3 & $\begin{array}{l}\text { Hasil Belajar siswa } \\
\text { Awalan Pa } \\
\text { Cara Melempar Pi } \\
\text { Cara Melempar Pa } \\
\text { Sikap AkhirPa } \\
\text { Sikap AkhirPi }\end{array}$ & $\begin{array}{l}95 \% \\
70 \% \\
80 \% \\
80 \% \\
60 \%\end{array}$ & $\begin{array}{l}\text { Perlu ditingkatkan kembali } \\
\text { terutama putri yang harus } \\
\text { mendapat perhatian lebih, } \\
\text { terutama pada aspek cara } \\
\text { melempar dan sikap akhir : } \\
\text { porsi mengulang di tambah } \\
\text { untuk putri }\end{array}$ \\
\hline
\end{tabular}

Hasil Tiap Aspek pada Tindakan:

1. Aktivitas siswa dalam belajar Lempar Cakram $80 \%$ Cukup

2. Aktivitas guru dalam mengajar Lempar Cakram 100\% Cukup

3. Hasil Belajar siswa Awalan Pa 100\% Ada peningkatan, bagi yang belum bisa menuntaskan belajar, di Remedial

4. Respon siswa terhadap proses Belajar Lempar Cakram 85\% Cukup

\section{Pembahasan}

\section{Aktivitas Siswa dalam Belajar Lempar Cakram}

Berdasarkan hasil observasi, aktivitas siswa pada siklus penelitian dengan 2 siklus penelitian pada proses pembelajaran Lempar Cakram menunjukan adanya peningkatan aktivitas siswa dari siklus pertama sampai siklus kedua seperti terlihat pada Tabel 8

Tabel 8

Hasil Tiap Aspek Selama 2 Siklus

\begin{tabular}{|l|l|l|c|}
\hline No & \multicolumn{1}{|c|}{ Aspek } & $\begin{array}{c}\text { Hasil tiap aspek } \\
\text { selama 2 siklus }\end{array}$ & $\begin{array}{c}\text { Siklus } \\
\text { Peningkatan }\end{array}$ \\
\hline 1. & $\begin{array}{l}\text { Aktivitas siswa dalam belajar } \\
\text { Lempar Cakram }\end{array}$ & $70 \% 80 \%$ & $10 \%$ \\
\hline 2. & $\begin{array}{l}\text { Aktivitas guru dalam mengajar } \\
\text { Lempar Cakram }\end{array}$ & $95 \% 100 \%$ & $5 \%$ \\
\hline 3. & $\begin{array}{l}\text { Hasil Belajar siswa Awalan Pa } \\
\text { Hasil Belajar siswa Awalan Pi }\end{array}$ & $95 \% 100 \%$ & $5 \%$ \\
\hline 4. & $\begin{array}{l}\text { Respon siswa terhadap proses } \\
\text { belajar Lempar Cakram }\end{array}$ & $85 \% 80 \%$ & $10 \%$ \\
\hline
\end{tabular}

Berdasarkan hasil observasi aktivitas siswa pada dua siklus penelitian pada pembelajaran Lempar Cakram dengan piring plastik menunjukan adanya peningkatan aktivitas siswa dari siklus pertama sampai siklus kedua seperti terlihat pada Tabel 9.

\begin{tabular}{|c|c|c|}
\hline Nomor & $\begin{array}{c}\text { Siklus } \\
\text { Penelitian }\end{array}$ & $\begin{array}{c}\text { Tindakan } \\
\text { Aktifitas }\end{array}$ \\
\hline 1 & Pertama & $70 \%$ \\
\hline 2 & Kedua & $80 \%$ \\
\hline & Rata-rata & $75 \%$ \\
\hline
\end{tabular}

Dari Tabel 9 di atas, terlihat bahwa siklus pertama aktivitas siswa mencapai $70 \%$, kemudian pada siklus kedua mencapai $85 \%$ ini berarti ada peningkatan $15 \%$ setelah ada treathment atau perbaikan pada siklus kedua, sehingga rata-rata keaktifan siswa selama dua siklus adalah $75 \%$. Mengacu pada Indikator Keaktifan Siswa pada Tabel 2, kisaran angka 75\% memiliki kriteria Aktif. Dengan kata 
lain, siswa selama mengikuti pembelajaran Lempar Cakram dengan media modifikasi piring plastik bergerak aktif baik saat mendapat tugas dari guru atau pun inisiatif sendiri.

\section{Aktivitas Guru Dalam Mengajar Lempar Cakram}

Tabel 10Aktivitas Guru

\begin{tabular}{|c|c|c|}
\hline Nomor & $\begin{array}{c}\text { Sik-1us } \\
\text { Penelitian }\end{array}$ & $\begin{array}{c}\text { Tindakan } \\
\text { Aktifitas }\end{array}$ \\
\hline 1 & Pertana & $95 \%$ \\
\hline 2 & Kedua & $100 \%$ \\
\hline & Rata-rata & $97,5 \%$ \\
\hline
\end{tabular}

Berdasarkan hasil pengamatan oleh rekan guru aktivitas guru dalam mengajar Lempar Cakram dengan media modifikasi piring plastik mengalami kenaikan aktivitas. Pada Tabel 10 nampak bahwa aktivitas mengajar guru pada siklus pertama mencapai tingkat pencapaian $95 \%$, sedangkan pada siklus kedua setelah melakukan treatment pada proses pembelajaran, aktivitas guru mencapai $100 \%$. Ini berarti ada kenaikan aktivitas guru sebesar 5\%, sehingga rata-rata aktivitas gurupada dua siklus mencapai 97,5\%.

Mengacu pada Indikator Aktivitas Guru pada Tabel 3, besaran angka 97,5\% termasuk kriteria Sangat Aktif. Ini artinya guru dalam mengajar betul-betul sesuai dengan skenario pembelajaran atau RPP.

\section{Hasil Belajar}

\begin{tabular}{|c|c|c|c|c|}
\multicolumn{5}{|c|}{ Tabel 11 Hasil Belajar Siswa } \\
\hline \multirow{2}{*}{ No } & Siklus Penelitian & Aspek & $\begin{array}{c}\text { Jenis } \\
\text { Kelamin }\end{array}$ & $\begin{array}{c}\text { Ketuntasan } \\
\text { Belajar }\end{array}$ \\
\hline 1 & Pertama & Awalan & $\mathrm{Pa}$ & $95 \%$ \\
& & Cara Melempar & $\mathrm{Pi}$ & $70 \%$ \\
& & Pa & $80 \%$ \\
& & Sikap Akhir & $\mathrm{Pi}$ & $60 \%$ \\
& & & $\mathrm{~Pa}$ & $80 \%$ \\
& & Awalan & $\mathrm{Pa}$ & $100 \%$ \\
& & & $\mathrm{Pi}$ & $80 \%$ \\
& & Cara Melempar & $\mathrm{Pa}$ & $90 \%$ \\
& & & $\mathrm{Pi}$ & $80 \%$ \\
& & Sikap Akhir & $\mathrm{Pa}$ & $90 \%$ \\
& & & $\mathrm{Pi}$ & $80 \%$ \\
\hline
\end{tabular}

Berdasarkan hasil tes praktik yang dilakukan kepada siswa, dari mulai awalan, cara melempar, dan sikap akhir Lempar Cakram, pada akhir siklus ternyata mendapat kenaikan.

Dari Tabel 11 terlihat bahwa untuk siklus pertama hasil tes praktik Awalan mencapai, putri $70 \%$, dan putra 95\%. Ini artinya, ada sebanyak 12 orang siswa putri yang mampu menuntaskan pembelajaran dari 17 orang, dan ada 17 orang siswa putra yang mampu menuntaskan pembelajaran dari 18 orang.

Masih pada siklus pertama, hasil tek praktik cara melempar mencapai, putri $60 \%$ dan putra $80 \%$. Ini artinya, ada sebanyak 10 orang putri yang mampu menuntaskan pembelajaran, dan 14 orang putra yang mampu menuntaskan pembelajaran.

Dari siklus pertama, hasil tes praktik sikap akhir mencapai $65 \%$ putri, dan $80 \%$ putra. Ini artinya ada 11 orang putri yang mampu menuntaskan pembelajaran, dan ada 14 orang putra yang mampu menuntaskan pembelajaran.

Pada siklus kedua dari Tabel 10 terlihat ada peningkatan pada tes praktik tiap aspek. Pada tes praktik awalan mencapai $100 \%$ putra, dan $80 \%$ putri. Ini berarti bahwa ada 18 orang siswa yang mampu menuntaskan pembelajarannya, artinya untuk putra semua siswa mampu menuntaskan pembelajarannya, dan untuk putri ada 14 orang yang mampu menuntaskan pembelajarannya.

Pada tes praktik cara melempar terlihat mencapai $90 \%$ putra dan $80 \%$ putri. Ini berarti ada sebanyak 16 orang putra yang mampu menuntaskan pembelajaran, dan 14 orang siswa putri yang mampu menuntaskan pembelajaran.

Sementara pada tes praktik sikap akhir persentase mencapai $90 \%$ putra dan $80 \%$ untuk putrid. Ini artinya bahwa ada 16 orang putra yang mampu menuntaskan pembelajaran, dan ada 14 orang putri yang mampu menuntaskan pembelajaran.

Aspek Awalan pada siklus pertama mencapai $95 \%$ putra, dan $70 \%$ untuk putri, sedangkan pada siklus kedua putra mencapai $100 \%$ dan putri $80 \%$. Ada kenaikan 5\% untuk putra dan ada lonjakan kenaikan $20 \%$ untuk putri, dan rata-rata ketuntasan belajar untuk aspek Awalan mencapai $97,5 \%$ putra dan putri mencapai $75 \%$. Mengacu pada Indikator Hasil Belajar Siswa pada Tabel 1, persentase tersebut menunjukan bahwa pembelajaran Awalan pada Lempar Cakram dengan menggunakan media modifikasi piring 
plastik, berkategori Sangat Efektif untuk putra dan efektif untuk putri.

Aspek Cara Melempar pada siklus pertama mencapai $80 \%$ putra, dan $60 \%$ untuk putri, sedangkan pada siklus kedua putra mencapai $90 \%$ dan putri $80 \%$. Ada kenaikan $10 \%$ untuk putra dan ada lonjakan kenaikan $20 \%$ untuk putri, dan rata-rata ketuntasan belajar untuk aspek Awalan mencapai 85\% putra dan putri mencapai $70 \%$. Mengacu pada Indikator Hasil Belajar Siswa pada Tabel 1, persentase tersebut menunjukan bahwa pembelajaran Cara Melempar pada Lempar Cakram dengan menggunakan media modifikasi piring plastik, berkategori Sangat Efektif untuk putra dan efektif untuk putri.

Aspek Sikap Akhir pada siklus pertama mencapai $80 \%$ putra, dan $65 \%$ untuk putri, sedangkan pada siklus kedua putra mencapai $90 \%$ dan putri $80 \%$. Ada kenaikan $10 \%$ untuk putra dan ada lonjakan kenaikan $15 \%$ untuk putri, dan rata-rata ketuntasan belajar untuk aspek Awalan mencapai $85 \%$ putra dan putri mencapai $72,5 \%$. Mengacu pada Indikator Hasil Belajar Siswa pada Tabel 1, persentase tersebut menunjukan bahwa pembelajaran Sikap Akhir pada Lempar Cakram dengan menggunakan media modifikasi piring plastik, berkategori Sangat Efektif untuk putra dan efektif untuk putri.

\section{KESIMPULAN}

Berdasarkan hasil temuan, analisis data dan refleksi pada setiap siklus serta pembahasan yang telah disajikan dalam babbab terdahulu, dapat dikemukakan Penelitian Tindakan Kelas dengan judul "Meningkatkan Efektivitas Belajar PJOK Materi Lempar Cakram dengan Menggunakan Media Modifikasi Piring Plastik pada Siswa Kelas VI SDN 1 Darmaji Tahun Pelajaran 2016/2017, Jumlah Sampel dalam penelitian ini sebanayak 28 Siswa yaang terdiri dari 12 putra dan 16 putri perempuan. Dengan hasil penelitian sebagai berikut;

Pertama, aktivitas siswa selama mengikuti proses pembelajaran Lempar Cakram dengan menggunakan media modifikasi piring plastik di kategorikan aktif. Dan setelah dilakukan siklus kedua, aktivitas siswa mengalami peningkatan keaktifan ratarata sebesar $75 \%$. Kalau mengacu pada
Indikator Keaktifan Siswa maka besaran keaktifan sebesar $75 \%$ termasuk kriteria Aktif.

Kedua, bahwa aktivitas mengajar guru pada siklus pertama mencapai tingkat pencapaian 95\%, sedangkan pada siklus kedua setelah melakukan treatment pada proses pembelajaran, aktivitas guru mencapai $100 \%$. Ini berarti ada kenaikan aktivitas guru sebesar 5\%, sehingga rata-rata aktivitas guru pada dua siklus mencapai 97,5\%. Mengacu pada Indikator Aktivitas Guru, besaran angka 97,5\% termasuk kriteria Sangat Aktif.

Ketiga rata-rata Ketuntasan Belajar untuk aspek Awalan mencapai 97,5\% putra dan putri mencapai $75 \%$. Mengacu pada Indikator Hasil Belajar Siswa pada Tabel 1, persentase tersebut menunjukan bahwa pembelajaran Awalan pada Lempar Cakram dengan menggunakan media modifikasi piring plastik, berkategori Sangat Efektif untuk putra dan efektif untuk putri.

Rata-rata ketuntasan belajar untuk aspek Cara Melempar mencapai $85 \%$ putra dan putri mencapai $70 \%$. Mengacu pada Indikator Hasil Belajar Siswa pada Tabel 1, persentase tersebut menunjukan bahwa pembelajaran Cara Melempar pada Lempar Cakram dengan menggunakan media modifikasi piring plastik, berkategori Sangat Efektif untuk putra dan Efektif untuk putri.

Rata-rata Ketuntasan Belajar untuk aspek Sikap Akhir mencapai $85 \%$ putra dan putri mencapai $72,5 \%$. Mengacu pada Indikator Hasil Belajar Siswa pada Tabel 1, persentase tersebut menunjukan bahwa pembelajaran Sikap Akhir pada Lempar Cakram dengan menggunakan media modifikasi piring plastik, berkategori Sangat Efektif untuk putra dan Efektif untuk putri.

\section{SARAN}

Berdasarkan hasil penelitian tersebut maka penggunaan media modifikasi piring plastik dapat dijadikan sebagai salah satu refrensi dalam pemebelajaran PJOK

\section{DAFTAR PUSTAKA}

Arikunto, Suharsimi, 2002. Prosedur Penelitian Suatu Pendekatan Praktik. Jakarta PT. Rineksa Cipta

Artikel.http://ahkmadsudrajat.wordpress.com/ bahan-ajar/media-pembelajaran/ 
Bani Quraisy.Rivai, H Veithzal ( ) FaktorFaktor yang Mempengaruhi Efektivitas Belajar Mahasiswa.

Fahmi, S., Syahrir, S., \& Kurniawan, A. (2018). Penerapan Metode Pembelajaran Problem Solving Untuk Meningkatkan Motivasi Dan Kemampuan Pemecahanmasalah Matematika Siswa Kelas Viii B Smp Negeri 3 Batukliang Tahun Pelajaran 2016/2017. Jurnal Media Pendidikan Matematika, 5(1), 85-89.

Roji. 2016. Penjaskes 3, Jakarta; Intan Parawara

Sajono, 2016. Pembinaan dan Kondisi fisik, Jakarta: Depdikbud Dirjen Dikti

Slamet, S.R. 2014.Penjaskes 3. Jakarta; Tiga Serangkai

Sudrajat, Ahkmad (2017). Media Pembelajaran.

Surya, Mohamad (2014). Psikologi Pembelajaran \& Pengajaran. Bandung. Pustaka. 